\title{
Species diversity of root rot pathogens of apple tree of the genus Fusarium Link in Southern Russia
}

\author{
Irina Astapchuk*, Galina Yakuba, and Andrei Nasonov \\ FSBSI «North Caucasian Regional Research Institute of Horticulture, Viticulture, Wine-making», \\ 40 - Years of Victory, 39, Krasnodar, 350901, Russia
}

\begin{abstract}
For horticulture in the North Caucasus, and Southern Russia as a whole, root rot of fruit crops is a serious problem, especially in nurseries and young gardens. In recent years, the harmfulness of species of the genus Fusarium Link as pathogens of root rot in the apple tree of domestic Malus domestica Borkh has been increasing. As a result of the studies, 115 samples of seedlings from four examined regions of Southern Russia were studied, 264 fungal isolates were isolated, among which 11 species of the genus Fusarium were found. The composition and occurrence of species were heterogeneous at its various sampling points. So, in the industrial gardens of the Krasnodar Territory and Karachay-Cherkess Republic, species F. sporotrichioides Sherb. and F. oxysporum Schltdl. prevailed, in the Belgorod region - F. sambucinum Fuskel, in the Rostov region $F$. sporotrichioides and F. proliferatum Matsush. The most common pathogens of rotting roots of apple seedlings in the entire studied sample were: F. sporotrichioides - 81 isolates, F. proliferatum - 37 isolates and F. oxysporum - 35 isolates. The rare species among the sample were $F$. avenaceum - isolates, as well as the pathogens that we isolated for the first time in the region as rot pathogens of $F$. solani (Mart.) Sacc. and $F$. poae (Peck) Wollenw.
\end{abstract}

\section{Introduction}

Root and near root rot - diseases that cause damage to the root system, root neck and the base of the stem or wood, causing withering and death of the whole plant. Root rot is common in both open and protected ground, often leading to significant crop losses. Fusarium root rot is caused by a complex of species of the genus Fusarium Link and is a serious problem for agriculture, as it spreads on a large scale and affects many crops: cereals, oilseeds, vegetables, berries, stone fruits, pome crops and others.

Species of the genus Fusarium belong to facultative-saprotrophic fungi and, upon transition to parasitization, are characterized by a wide specialization in host plants belonging to different families and classes. As the analysis of literature shows, the composition of the Fusarium complex of root rot pathogens varies depending on the host plant and location.

"Corresponding author: irina_astapchuk@mail.ru 
For example, in the Tambov region, among the causative agents of sunflower root rot F. oxysporum Schltdl., including F. oxysporum var. orthoceras, F. sporotrichioides Sherb., $F$. verticillioides (Sacc.) Nirenberg, F. tricinctum (Corda) Sacc., F. sambucinum Fuskel, in the Krasnodar Territory - F. oxysporum and F. sporotrichioides. In Western Siberia and the Trans-Urals, among the causative agents of root rot of cereals, the following species predominate: F. avenaceum (Fr.) Sacc., F. oxysporum, F. graminearum Schwabe, $F$. sambucinum, in central Russia - F. graminearum, F. culmorum (WGSm.) Sacc., F. solani (Mart.) Sacc., F. semitectum Berk. \& Ravenel. In the Moscow Region, the frequency of micromycete isolation from the roots of wilting raspberries and from the root soil of Fusarium spp. - $20 \%, F$. sambucinum - $30 \%$, from the roots of wilting plants of wild strawberries Fusarium spp. - $22 \%$. Mycological analysis of dead cherry plants in the Izmailovsky nursery (Moscow region) showed that rotten roots were inhabited by $F$. lateritium Nees - $37 \%$, F. sambucinum - up to $50 \%$ and F. gibbossum App. et Wr. $25 \%$. According to colleagues, fungi of the genus Fusarium as pathogens of root rot cause great damage to vegetable crops. So, in Pakistan, bell pepper is affected by F. equiseti (Cda) Sacc. [1], in Japan, lettuce - F. oxysporum f. sp. lactucae [2], onions - F. oxysporum (F. redolens) [3], in the USA (Alabama) sweet potato is affected by $F$. solani [4], tomato $F$. oxysporum f. sp. radicis-lycopersici [5], common bean - F. solani f. sp. phaseoli [6], in the Netherlands asparagus $-F$. oxysporum f. sp. asparagi and $F$. proliferatum [7], in Canada soybean - F. proliferatum [8].

In recent years, there has been an increase in the occurrence of species of the genus Fusarium in the root rot complex of seedlings of the domesticated apple - Malus domestica Borkh. [9]. The degree of their harmfulness varies depending on their specialization, fruit culture, age of plantations, climatic zone, the degree of sensibility of varieties and rootstocks, the growth rate of trees, ongoing protective measures, and, in general, depending on the technology of growing plantations. Pathogens of root rot accumulate in the soil and are able to spread with planting material. For example, the frequency of selection of fungi from drying seedlings (roots and aerial parts) of apple trees in nurseries and young gardens was: $62 \%$ $F$. sambucinum in Belarus, $F$. sambucinum $41 \%$, F. lateritium $41 \%$ and $F$. roseum Link $50 \%$ in the Moscow region. Species composition of micromycetes in the root soil of an apple tree from Kabardino-Balkar Republic: Fusarium spp. - 40 \%, F. sambucinum - 44 \% [9]. There is evidence of damage to the roots of apple trees in certain regions of Africa $F$. oxysporum, $F$. solani and $F$. avenaceum [10], in Tunisia

F. solani (40\%), F. proliferatum, F. equiseti, F. oxysporum (100\%) [11], in China Fusarium spp. [12], in Italy F. oxysporum and F. solani [13], as well as in India F. oxysporum, F. solani, F. equiseti, and Fusarium spp. [14].

As can be seen from the analysis of the literature, over the past 20 years, there has been a tendency to increase the spread of root rot pathogens from the genus Fusarium; its species composition is very variable and varies in different climatic zones, including the domesticated apple [15-19]. For horticulture in the North Caucasus, and for the South of Russia as a whole, root rot of fruit crops is a serious problem, especially in nurseries and young gardens, respectively, the study of the species composition of the causative agents of this disease is actual. The aim of our work was to determine the species composition of the pathogens of root rot of apple trees caused by fungi of the genus Fusarium in Southern Russia.

\section{Materials and methods}

Research conducted in 2019-2020 in the laboratory of biotechnological control of phytopathogens and phytophages of FSBSI «North Caucasian Regional Research Institute of Horticulture, Viticulture, Wine-making». The selection of one- and two-year-old grafted 
seedlings with symptoms of root rot damage was carried out in February-March 2019 by routine examinations according to generally accepted methods [9] in industrial gardens of the South of Russia: Karachay-Cherkess Republic (KCR), Rostov Region, Krasnodar Territory and Belgorod Region (Figure 1).

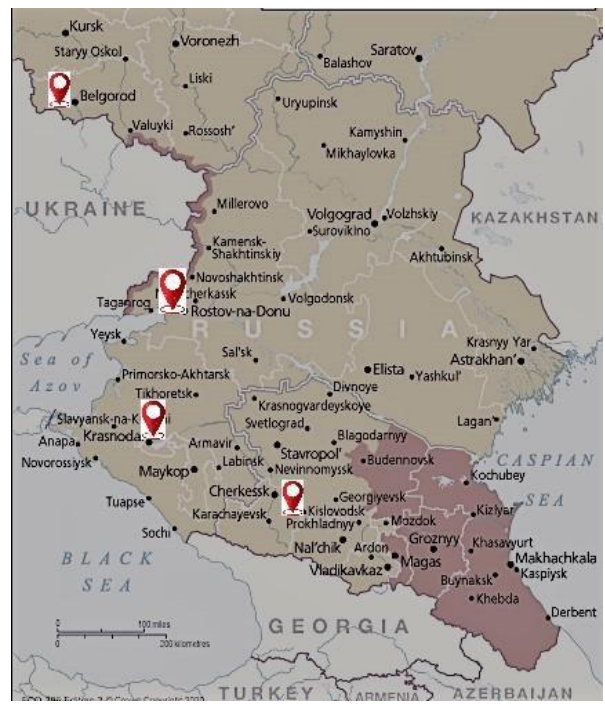

Fig. 1. Areas of collection of samples affected by root rot (from top to bottom): Belgorod Region, Rostov Region, Krasnodar Territory and Karachay-Cherkess Republic (KCR) (the resource was used to create the picture https://www.gov.uk/foreign-travel-advice/russia)

The objects of research were pure cultures of fungi of the genus Fusarium - pathogens of root rot of the apple tree. Isolation of micromycetes was carried out under sterile conditions from the central and lateral roots, the root neck using the microbiological method [10] on potato-glucose agar (PGA). Then, after 5-7 days of growth of the mycelium of the fungus, monospore cultures were obtained on the PGA and incubated at a temperature of $24-26^{\circ} \mathrm{C}$ (Figure 2). Determination of the species composition of mycopathogens was carried out using standard techniques and domestic and foreign definitive literature [20]. The names of the species, as well as their nomenclature, are given in accordance with modern taxonomic systems [20] and databases http://www.mycobank.org/ and http://www.indexfungorum.org/.
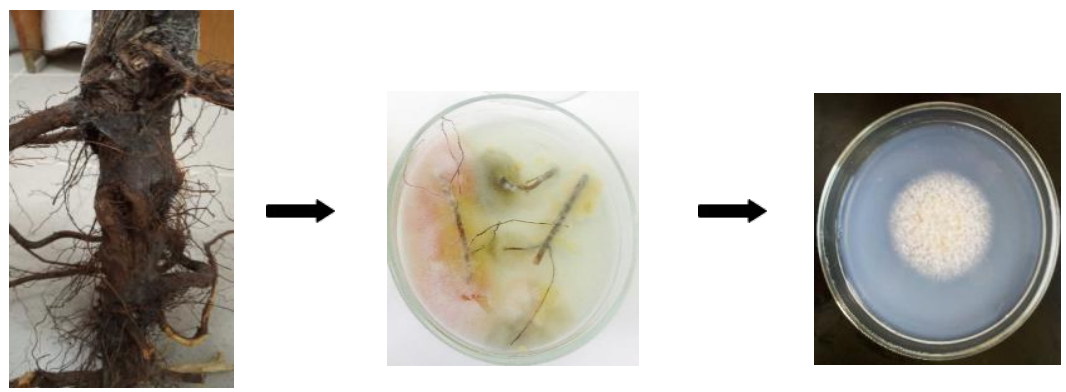

Fig. 2. Isolation of in vitro fungi from the roots, root neck of affected apple seedlings (original)

The calculation of similarity coefficients, or community indices, using lists of species of communities of fungi of the genus Fusarium was calculated using the Jaccard index Kj. 
These coefficients are equal to 1 in the case of complete coincidence of community species and equal to 0 if the samples do not include common species.

$$
\mathrm{Kj}=\mathrm{Nab} /(\mathrm{Na}+\mathrm{Nb}-\mathrm{Nab})
$$

where $\mathrm{Nab}$ is the number of common species in communities $\mathrm{A}$ and $\mathrm{B}$;

$\mathrm{Na}$ is the number of species in community $\mathrm{A}$;

$\mathrm{Nb}$ is the number of species in community $\mathrm{B}$.

\section{Results and discussion}

115 samples of seedlings from four examined regions of Southern Russia were studied. In the process of analysis of affected plants in all four points of selection, 11 species of the genus Fusarium were identified. The species $F$. poae (Peck) Wollenw. and $F$. solani as pathogens rotting apple roots we were first discovered in the region (Table 1). As a result of the studies, 264 isolates of species of the genus Fusarium were isolated.

The most common species in Southern Russia turned out to be species F. sporotrichioides and $F$. oxysporum, which were found at all studied points (Table 1). Moreover, the species $F$. sporotrichioides leads in the total number of isolated isolates, the share of which is $31 \%$ of the total sample of pure cultures. Then, as the occurrence decreases, the following species go: F. proliferatum, F. equiseti and $F$. sambucinum, $F$. langsethiae and $F$. dimerum, which were found in samples from three sampling points. Species $F$. culmorum was found only in the Rostov region and in the Krasnodar Territory, and the species $F$. solani and F. poae were unique to the root rot of apple trees from the gardens of the Belgorod region.

Table 1. The incidence of root rot pathogens of domesticated apple Fusarium spp. in the South of Russia (2019)

\begin{tabular}{|c|c|c|c|c|c|}
\hline \multirow[b]{2}{*}{ Species* } & \multicolumn{4}{|c|}{ The frequency of occurrence of pathogens, $\%$} & \multirow{2}{*}{$\begin{array}{l}\text { The } \\
\text { number of } \\
\text { isolates, } \\
\text { pieces }\end{array}$} \\
\hline & $\begin{array}{l}\text { Rostov } \\
\text { region }\end{array}$ & $\begin{array}{l}\text { Krasnodar } \\
\text { region }\end{array}$ & $\begin{array}{l}\text { Belgorod } \\
\text { region }\end{array}$ & $\begin{array}{l}\text { Karachay- } \\
\text { Cherkess } \\
\text { Republic }\end{array}$ & \\
\hline F. sporotrichioides & 32.1 & 28.5 & 29.6 & 35.0 & 81 \\
\hline F. proliferatum & 25.0 & 8.1 & 2.9 & - & 37 \\
\hline F. oxysporum & 3.5 & 20.4 & 8.8 & 40.0 & 35 \\
\hline F. equiseti & 16.5 & 6.4 & - & 10.0 & 26 \\
\hline F. sambucinum & 6.2 & 2.0 & 50.0 & - & 26 \\
\hline F. langsethiae & 14.2 & 2.0 & - & 15.0 & 21 \\
\hline F. dimerum & 0.8 & 15.3 & 2.9 & - & 17 \\
\hline F. culmorum & 1.7 & 12.2 & - & - & 14 \\
\hline F. avenaceum & - & 5.1 & - & - & 5 \\
\hline F. solani & - & - & 2.9 & - & 1 \\
\hline F.poae & - & - & 2.9 & - & 1 \\
\hline \multicolumn{5}{|l|}{ Total isolates, pieces } & 264 \\
\hline
\end{tabular}

In the course of the work, the variation in the species composition of the pathogenic mycocomplex depending on the selection point was confirmed.

In industrial gardens of the Rostov region, the largest number of seedlings affected by rot was studied - 48 pcs., in the roots of which 8 species of the genus Fusarium were found and 112 strains were isolated. Among the isolated isolates, the species F. sporotrichioides 
and $F$. proliferatum (Matsushima) Nirenberg prevailed: 32 and $25 \%$ respectively. Species of F. equiseti and F. langsethiae Torp \& Nirenberg met with a frequency of $15 \%$; $F$. sambucinum species were distinguished in $6 \%$ of cases from the entire sample of samples, the remaining species - with a frequency of less than $5 \%$.

In the Krasnodar Territory, 38 seedlings were studied, the largest number of species from the studied sample was discovered - 9 pcs. and 98 strains were isolated. Among the obtained fungal isolates, the species $F$. sporotrichioides predominated $-28 \%$, the species $F$. oxysporum was present in $20 \%$ of cases, the species $F$. culmorum and $F$. dimerum Penzig Sacc. - in 13-15\% of cases, other species - with a frequency of less than $10 \%$.

In the Belgorod region, 17 affected samples of seedlings were studied, 7 species were identified and 34 isolates were obtained, half of which was represented by the species $F$. sambucinum. Species $F$. sporotrichioides was isolated with a frequency of $30 \%$; the share of other species was less than $10 \%$.

In industrial gardens of the KCR, 12 samples of apple seedlings were examined, from the damaged roots of which 4 species of fungi of the genus Fusarium were isolated and 20 isolates were obtained. The most common species were F. oxysporum $-40 \%$ and F. sporotrichioides $-35 \%$.

The calculation of the Jaccard index showed that the minimum degree of similarity in the species composition of pathogens of rotting apple roots was between the gardens of the Belgorod region and the KCR, the maximum between the gardens of the Krasnodar Territory and the Rostov Region, the degree of similarity of the species composition between the other sampling points was average (0.44-0.50) (Table 2).

Table 2. Similarity coefficients of communities of species of the genus Fusarium from different selection points according to the Jaccard index $(\mathrm{Kj})$

\begin{tabular}{|l|c|c|c|}
\hline \multicolumn{1}{|c|}{ Areas } & Rostov region & Belgorod region & $\begin{array}{c}\text { Karachay-Cherkess } \\
\text { Republic }\end{array}$ \\
\hline Krasnodar region & 0.88 & 0.45 & 0.44 \\
\hline Rostov region & - & 0.50 & 0.50 \\
\hline Belgorod region & - & - & 0.22 \\
\hline
\end{tabular}

Studying of the species structure of the community of fungi of the genus Fusarium of the Belgorod region showed that, on the one hand, it was characterized by unique species $F$. solani and $F$. poae. On the other hand, F. sambucinum was represented as the dominant species $-50 \%$, whose share in the other selection points studied by us was $0-5 \%$. The species structure of the pathogen community in the KCR was less diverse. The Belgorod region and the KCR were the most distant sampling points. Perhaps this led to the greatest differences in the species structure of fungi between them. The Krasnodar Territory and the Rostov Region (89\%) turned out to be closest in the total number of coincident species, and according to our data, the Krasnodar Territory and the Karachay-Cherkess Republic were found here in terms of the composition of the dominant species, F. sporotrichioides and $F$. oxysporum were found here. The analysis of our data made it possible to note that the ecological, climatic and geographical factors could influence the species composition of the genus Fusarium, pathogens of root rot of apple trees.

\section{Conclusion}

According to the results of the study, a wide species diversity of representatives of the genus Fusarium (11 species) in the complex of pathogens that cause root rot of apple trees in the South of Russia can be noted. The most common pathogens of rotting roots of apple seedlings in the entire studied sample were: F. sporotrichioides - 81 isolates, 
F. proliferatum - 37 isolates and F. oxysporum - 35 isolates. Rarely encountered were $F$. avenaceum - 5 isolates, as well as $F$. solani and $F$. poae. The composition and occurrence of species were heterogeneous at different points in the studied region. Thus, species $F$. sporotrichioides and $F$. oxysporum prevailed in the Krasnodar Territory and KCR, in the Belgorod region F. sambucinum and in the Rostov region, F. sporotrichioides and $F$. proliferatum. These differences can be explained by the ecological and climatic features of these areas, which determine the competitive advantage of one or another pathogenic species, as well as the origin of planting material.

\section{References}

1. F. Naz, Journal of Plant Pathology, 589 (2018), https://link.springer.com/article/10.1007/s42161-018-0093-Z
2. $\mathrm{M}$.
Fujinaga,
Plant
Pathol.,
205-206,
(2001), https://link.springer.com/article/10.1007/PL00013012

3. A. Shinmura, Plant Pathol., 265 (2002), https://doi.org/10.1007/PL00013090

4. C. Stevens, Crop Protection, 18, 463-470, https://www.sciencedirect.com/science/article/abs/pii/S0261219499000459

5. G. Fazio, $\quad$ Euphytica, 105, 205-210, https://link.springer.com/article/10.1023/A:1003497719705

6. K.A.

Schneider, https://www.researchgate.net/publication/251304486 Genetic analysis of resistance to F usarium root rot in common bean

7. R.P. Baayen, European Journal of Plant Pathology, 106, 907-912, (2000), https://link.springer.com/article/10.1023/A:1008766707266
8. K.F.
Chang,
Crop
Protection,
67, 52-58,
(2015),

https://www.sciencedirect.com/science/article/abs/pii/S0261219414003032

9. С.Е. Головин, Плодоводство и ягодоводство России, 29(1), 111-120, (2012) https://www.elibrary.ru/download/elibrary 17330107 34412667.pdf

10. W. Botha, M. Mazzola, C. Spies, 130(2), 215-229, (2011), https://www.researchgate.net/publication/225480437 Characterization of fungi Fusarium and Rhizoctonia and oomycetes Phytophthora and Pythium associated with apple or chards in South Africa

11. S. Mannai, N. Horrigue-Raouani, N. Boughalleb-M'Hamdi, 1-2, 14-34, (2018), https://www.researchgate.net/publication/336848028_Characterization_of_Fusarium_speci es associated with apple decline in Tunisian nurseries

12. W. Gongshuai, Y. Chengmiao, P. Fengbing, W. Xiaobao, X. Li, W. Yanfang, W. Jinzheng, T. Changping, C. Jie, M. Zhiquan, Horticultural Plant Journal 4(5), 175-181, (2018) https://www.sciencedirect.com/science/article/pii/S2468014118301468

13. M. Kelderer, L. Manici, F. Caputo, M. Thalheimer, Plant Soil 357, 381-393, (2012) https://link.springer.com/article/10.1007/s11104-012-1172-0

14. M. Sharma, A. Kapatia, S. Kulshrestha, Biosciences biotechnology research Asia, 13(1), 463-468, (2016) http://www.biotech-asia.org/vol13nol/analysis-of-genetic-diversityamongst-fusarium-spp-associated-with-root-rot-of-apple/

15. M. Mazzola, Phytopathology, 88, https://doi.org/10.1094/phyto.1998.88.9.930

16. L.M. Manici, European Journal of Agronomy, 33, 188-196, (2010), https://doi.org/10.1016/j.eja.2010.05.005

17. Y.T. Tewoldemedhin, Soil Biology and Biochemistry, 43, 1917-1927, (2011), https://doi.org/10.1016/j.soilbio.2011.05.014 
18. L.M. Manici, Applied Soil Ecology, 72, 207-214, (2013), https://doi.org/10.1016/j.apsoil.2013.07.011

19. M. Kelderer, Plant and Soil, 357, 381-393, (2012), https://link.springer.com/article/10.1007/s11104-012-1172-0

20. Г.В. Якуба, И.Л. Астапчук, А.И. Насонов, Плодоводство и виноградарство юга России, 60(6) 148-162, (2019), http://journalkubansad.ru/pdf/19/06/15.pdf 